\title{
AN ANALYSIS OF THE FACTORS THAT INFLUENCE STUDENT PERFORMANCE: A FRESH APPROACH TO AN OLD DEBATE
}

\section{SANJIV JAGGIA and ALISON KELLY-HAWKE}

There is a general consensus that student performance at all levels has been deteriorating. Despite numerous attempts by researchers to link school expenditures with student performance, a clear relationship does not exist. Since a number of difficulties plague earlier studies, this paper attempts to remedy these problems by offering a better data design and a sounder methodology. This study uses the 1992 Massachusetts Educational Assessment Program (MEAP) test scores from 4th. 8th. and 12th grade students to measure student performance. Since each student's grade falls into one of five possible categories, the application of an ordered logit model incorporates the natural ordering of the MEAP scores. The results indicate that family background and the stability of a community are the main factors affecting student performance. The data suggest that higher levels of spending have no consistent or systematic relation with student performance. (JEL $12, \mathrm{C} 25)$

\section{ABBREVIATIONS}

LR: Likelihood ratio

MEAP: Massachusetts Educational Assessment Program

\section{INTRODUCTION}

There is a general consensus that the performance of students exiting the elementary and secondary school system has been slipping. In the past it was popular to believe that raising educational standards meant investing more money in schools; i.e., the best schools were the 
ones that spent the most money. Today, inner-city schools typically spend at least $50 \%$ more on per pupil expenditures than the U.S. average, yet these schools are failures by almost any measure. This suggests that spending more on a school does not necessarily mean that its students will learn more.

Most research attempting to link student performance and expenditures stems from the conclusions drawn from the Coleman report (Coleman et al., 1966). In brief, this report finds that school expenditures have only a minor influence on student achievement. Instead, variations in family background and in the backgrounds of other students in the school are the primary determinants of students' performance. Nearly three decades after the Coleman report, Hanushek (1986, 1989, 1996) surveys most of the recent published empirical literature and also concludes that there is no clear relationship between school expenditures and student performance. Hedges et al. (1994) and Hedges and Greenwald (1996) reanalyze essentially the same studies summarized by Hanushek, yet their statistical evidence suggests that school expenditures have a statistically significant and positive influence on student achievement. Sander (1993) and Ferguson and Ladd (1996) also conclude that school expenditures can have significant effects on educational outcomes.

Other studies explore the relationship between expenditures on schools and future earnings and arrive at the same conflicting results. Card and Krueger (1992) estimate the relationship between the return to schooling in a given state and several attributes of a state's educational system. Their results indicate that additional school resources are powerfully linked to increases in students' earnings as adults. Heckman et al. (1996) find that Card and Krueger's conclusions are very sensitive to their assumption of strict linearity. Once this assumption is relaxed, the importance of school resources shrinks dramatically. For example, school resources appear to 
have little or no effect on the earnings of workers who have not completed college. Lastly, Betts (1995) examines three commonly used measures of school quality, class size, teachers' salaries, and teachers' level of education, and also finds no significant relation between them and subsequent earnings of workers.

From an economist's point of view, the connection between money and education is maddeningly unclear. A number of difficulties plague earlier studies on this subject. This paper seeks to remedy this state of affairs by offering a better data design and a sounder methodology. First, the data set is comprehensive and includes virtually every 4th, 8th, and 12th grade student in the state of Massachusetts. Other commonly used measures of student performance, like the SAT scores, are not reliable since they suffer from selectivity bias (Hanushek and Taylor, 1990) and are taken only by older students. Further, since each observation in the data set is for an individual school district and all school districts lie within the same state (following the same laws and regulations), the problem of omitted variable bias is reduced. This less aggregated data set contains more information about community characteristics and tends to produce more reliable estimates of the true impact of school expenditure on attainment (see Hanushek et al., 1996).

Second, the estimation method is statistically sound and captures the nonlinearities inherent in the model. ${ }^{1}$ This study uses the 1992 Massachusetts Educational Assessment Program (MEAP) test scores for the three aforementioned grade levels to measure student performance. Since MEAP scores can fall into one of five different categories, there is no unique dependent variable measuring student performance in this application. One could use the estimated average of MEAP scores in a community as a single value of the dependent variable. However, the use of

\footnotetext{
${ }^{1}$ Most studies in the area of education employ linear single equation regression (Stern, I489], although a number of studies use simultaneous equation estimation (Boardman et al., 1977).
} 
this average suppresses useful information and cannot capture movement between different categories of students' scores. Further, a commonly used linear model on this average would incorrectly assume that the marginal contribution of each regressor is constant and can thus lead to erroneous conclusions. The application of an ordered logit model appropriately captures the natural ordering of the dependent variable and any inherent nonlinearities.

This paper analyzes the effect of various factors that influence the probabilities of getting different grades. The findings are broadly supportive of the conclusions of the Coleman report. Family background and the stability of a community are the main factors influencing student performance. The data suggest that, in general, higher levels of spending are not associated with an improvement in student performance. Smaller class sizes lead to better achievement, but only in the early years of education.

This paper is organized as follows. Section II defines the data sources and model specification. Section III describes the econometric method used. In addition to presenting the results, section IV also provides an extensive simulation that analyzes the influence of both expenditures and socioeconomic factors on student performance. Section V concludes.

\section{DATA OVERVIEW AND MODEL SPEC IF ICATION}

A commonly accepted way to model educational performance is by using a production function approach (Ferguson and Ladd, 1996; lioxby, 1996). In the education context, this usually means a function in which the output is a measure of student achievement and the inputs include measures of school, family, and background. The following delineates the input and output variables in this study.

\section{A. The Dependent Variable}


The 1992 MEAP test, taken by virtually all 4th, 8th and 12th grade students, ${ }^{2}$ evaluates students according to their answers to a combination of open-ended, essay, and multiple-choice questions in reading, mathematics, science, and social studies. MEAP reports the percentage of students taking the test who, on the basis of their performance, fall into one of the following five categories: below Level 1, Level 1, Level 2, Level 3, and Level 4. The categories are analogous to letter grades; i.e., students scoring below Level 1 are basically receiving a grade of $\mathrm{F}$, while those scoring at Level 4 are receiving a grade of A. For a school district, the percentage of students falling into each category is observed. For example, in a representative town such as Abington, the percentages of $4^{\text {h }}$ grade students that fall into each category are observed as follows: 3\% at below Level 1, 34\% at Level 1, 42\% at Level 2, 19\% at Level 3, and 2\% at Level 4.

\section{B. The Independent Variables}

(i) Measures of School Inputs. In Hanushek's influential survey articles (1986, 1989, 1996), his tabulations reveal that essentially all studies use at least one of the following regressors as a principal indicator of school input: teacher-pupil ratio, teacher education, teacher experience, teacher salary, per pupil expenditures, administrative inputs, and facilities. He notes that these regressors are not necessarily listed in order of their degree of importance as measures of school inputs; rather, these regressors are listed (from highest to lowest) in order of the number of studies that use these regressors in the estimation process.

This study uses three regressors as principle indicators of school resources: the teacher-pupil ratio, per pupil expenditures, ${ }^{3}$ and per pupil administration expenditures. (For ease of exposition

\footnotetext{
${ }^{2}$ This analysis focuses on pupils enrolled in the regular day program, which offers a general course of instruction.
} 
later in the text, the teacher-pupil ratio is expressed as a percentage. In addition, per pupil expenditures are expressed in thousands of dollars and per pupil administration expenditures are expressed in hundreds of dollars.) These regressors shed light on the belief that an increase in school inputs improves student performance. For instance, those districts that have higher per pupil expenditures and/or smaller class sizes should have students that perform better. The regressor representing per pupil administration expenditures assesses whether a particular component of expenditure influences student performance.

(ii) Socioeconomic Background Measures. Two regressors reflect students' family background: the percentage of professionals and managers within a community and the percentage of single mothers within a community. Student achievement should be positively related to households where both parents are present and households where the parents are better educated. Two regressors gauge stability within a community: the percentage of rental units and the crime rate. One expects movement of students from the higher levels of achievement into the lower levels of achievement if the crime rate or the percentage of rental units increase within a community. Lastly, a dummy variable indicates whether or not a school district is located in an urban area. This variable further captures the notion that what might be true for one type of district, say an urban district, may not be true for another type of district, say a suburban district. ${ }^{4}$

Data for all variables are available from the Massachusetts School District Profiles (1993), the Massachusetts Municipal Profiles 199293, the 1990 Census of Population and Housing

\footnotetext{
${ }^{3}$ Per pupil expenditures are paid from funds appropriated by the districts from tax revenues and state aid. The amount of state aid varies by district. Factors that influence the amount of state aid that a particular district receives are the mean income level and the number of students that need special education and/or bilingual education. ${ }^{4}$ Various other variables that capture the economic status of the community are dropped because of adherence to the principle of parsimonious parametrization and also because of multicollinearity. For instance, a simple correlation matrix shows that real estate values and median income have a high correlation with the included percentage of professionals and managers variable. Other diagnostics for multicollinearity, including the variance inflation factor and condition numbers, confirm the choice of variables in the final model.
} 
(1992), Massachusetts Crime Statistics (1993), and Crime in the U.S. (1992, 1993). Table 1 summarizes the mean percentage of students falling into the five MEAP categories for 4th, 8th, and 12th grade students as well as the mean of each of the regressors.

\section{METHODOLOGY}

\section{[Insert Table 1]}

In many economic applications the dependent variable is discrete and represents an outcome of a decision between a finite set of alternatives. A variety of qualitative response models deal with this characteristic of the dependent variable (see, e.g., Amemiya, 1981; Greene, 1993). Further, in some applications, there are multinomial choice variables that are naturally ordered. Examples include opinion surveys (strongly agree, agree, disagree, and strongly disagree), insurance coverage (full, partial, none), bond ratings, and so on. In this application, a student's performance falls in one of the five categories that are naturally ordered. Even though the underlying dependent variable is continuous, only the discrete responses are observed. Thus, consider the following latent regression:

$$
y *=\beta^{\prime} x+\varepsilon,
$$

where $y^{*}$ refers to some unobserved measure of student performance. The following five values of the dependent variable are observed: 


$$
\text { (2) } \begin{aligned}
& y=0^{5} \quad \text { if } \quad y^{*}<\gamma_{0}, \\
& y=1 \quad \text { if } \quad \gamma_{0} \leq y^{*}<\gamma_{1}, \\
& y=2 \quad \text { if } \quad \gamma_{1} \leq y^{*}<\gamma_{2}, \\
& y=3 \quad \text { if } \quad \gamma_{2} \leq y^{*}<\gamma_{3}, \\
& y=4 \quad \text { if } \quad y^{*} \geq \gamma_{3} .
\end{aligned}
$$

5. For ease of exposition, Level 0 refers to below Level 1.

Here $\gamma_{i}$ is the unknown parameter to be estimated along with $\beta$. Further,

$$
\begin{gathered}
P(y=0)=P\left(y *<\gamma_{0}\right) \\
=P\left(\varepsilon<\gamma_{0}-\beta^{\prime} x\right)=F\left(\gamma_{0}-\beta^{\prime} x\right),
\end{gathered}
$$

where $F(z)$ is the distribution of $\varepsilon$. For an ordered logit model, a logistic distribution function for $\varepsilon$ is given by

$$
F(z)=\frac{\exp (z)}{1+\exp (z)}=\frac{1}{1+\exp (-z)} .
$$

Therefore,

$$
P(y=0)=1 /\left[1+\exp \left(\beta^{\prime} x-\gamma_{0}\right)\right]
$$

Similarly, the other four probabilities are calculated from logistic function (4). These probabilities are used to specify the following loglikelihood function that is maximized to obtain the parameter estimates:

$$
\begin{gathered}
£=\sum_{i=1}^{N} N_{i} \\
{\left[\sum_{j=0}^{4} \hat{P}\left(y_{i}=j\right) \ln P\left(y_{i}=j\right)\right],}
\end{gathered}
$$


where $p\left(y_{i}=j\right)$ refers to the proportion of students in the $i^{\text {th }}$ school who scored at the $j^{\text {th }}$ level and $n_{i}$ refers to the number of students in the $i^{\text {th }}$ school who took the exam. Further, given a constant term in $x, y_{0}$ is set to zero without any loss of generality in the estimation. ${ }^{5}$

In linear regression models, the coefficient 13 measures the marginal effect of the regressors on the dependent variable. The interpretation of 13 in the above ordered logit model is not straightforward. Not only is the effect of a given regressor nonlinear, but also its influence varies on each probability. For instance, the effect of spending more money on students is not constant on the probability of scoring at a particular level; it is also different for the five possible levels. Greene (1993) observes that most studies report only the significance of various regressors, ignoring the more important part of interpreting the coefficients. To capture the marginal effects of the regressors on the five probabilities, the partial derivative of each regressor is evaluated at its mean value. For instance, the effect of a one unit increase in the regressor $\mathrm{x}$ on the probability of a student scoring at Level 0 is

$$
\frac{\partial P(y=0)}{\partial x}=f\left(-\beta^{\prime} x\right) \beta
$$

where

$$
\begin{aligned}
f(z) & =\frac{\partial F(z)}{\partial z}=\frac{\exp (z)}{[1+\exp (z)]^{2}} \\
& =F(z)[1-F(z)] .
\end{aligned}
$$

The effect of the eight regressors on the other four probabilities is determined in a similar manner.

\section{RESULTS}

\footnotetext{
${ }^{5}$ Maximum likelihood estimates are obtained using the MAXLIK module of the GAUSS programming language. A consistent estimate of the variance-covariance matrix of the parameters is derived as: $H^{-1}\left(G^{T} G\right) H^{-1}$, where $H$ and $G$ denote the hessian and the gradient evaluated at the maximum likelihood estimates of the parameters, respectively.
} 
Tables 2, 3, and 4 show the results of the estimated ordered logit models for grades 4 , 8 , and 12, respectively. Column (1) of each table lists the estimates for the final model—the model that includes all school input variables. Arguably, multicollinearity may exist among the school input variables since per pupil expenditures are mostly a function of the teacher-pupil ratio and per pupil administration expenditures. To address this issue, the model is estimated without the teacher-pupil ratio and per pupil administration expenditures (column [2]). The model is also estimated without per pupil expenditures and with the teacher-pupil ratio and per pupil administration expenditures (column [3]). The results are robust to these different specifications, with all models pointing to the fact that increasing school inputs alone will not improve student performance. Thus, without any loss in generality, the remaining section focuses on the results of the final model as presented in column (1) of Tables 2-4. [Insert Table 2]

In the absence of a standard F-test, a likelihood ratio (LR) test is conducted to test the overall explanatory power of the model. The LR test is computed by taking twice the difference between the maximized log-likelihood values of the null hypothesis (constant only) and the alternative hypothesis (all regressors). The values of the resulting $\mathrm{X}^{2}(\mathrm{df}=8)$ test statistics imply that the model fit is good and the eight explanatory variables are jointly significant at any given level for each grade (see Tables 2-4). Further, in order to test the predictive power of the final model, the estimated ordered logit models are evaluated at mean regressors to compute the probabilities of student performance at various levels. Table 1 presents these probabilities underneath the actual average values of the dependent variables. A comparison of these probabilities to the actual average values indicates that these two values are extremely close to one another. For example, in the 12th grade the actual average percentage of students at various levels as well as the 
predicted percentages for these same levels are approximately 10, 31, 27,25, and 8, respectively. Thus, the model has excellent predictive abilities.

The results strongly suggest that higher levels of spending do not have any consistent or systematic relation with student performance. Per pupil expenditures is insignificant for all three grade levels. In fact, for the $4^{\text {h }}$ and $8^{\prime} \mathrm{h}$ grades the sign on this regressor is negative, implying an inverse relationship between spending and student performance. These results are consistent with those obtained by Hanushek, whose various studies conclude that increases in school expenditure have no systematic impact on student learning.

[Insert Table 3]

The influence of the teacher-pupil ratio variable is a bit ambiguous; it is positive and significant for the 4th grade, positive and insignificant for the 8th grade, and negative and significant for the 12th grade. ${ }^{6}$ Hanushek (1996) also reports conflicting results in his summary of 377 studies, most of which found the relationship between the teacher-pupil ratio and student performance to be insignificant. Among the studies that find a statistically significant relationship, almost as many show that increases in class sizes cause improvements in student performance as show the reverse. The results in this study indicate that smaller class sizes lead to better student performance only in the early stages of education. Ferguson (1991) also reports that the positive influence of smaller class sizes is restricted to the primary grades.

Another interesting finding is that per pupil administration expenditures is negatively related to student performance for all grade levels and is significant at the I\% level for the $4^{\text {th }}$ grade and the 8th grade. Apparently, if per pupil administration expenditures increases, then student

\footnotetext{
${ }^{6}$ Note, however, that the teacher-pupil ratio is generally an indicator of class size, and to the extent that this ratio differs from the actual class size, a measurement error exists (Akerhielm, 1995). Thus, one should use care when interpreting the results regarding this regressor.
} 
performance slips. ${ }^{7}$ This result becomes apparent once the partial derivatives of this regressor are analyzed, an issue addressed further below.

As mentioned in section III, it is difficult to interpret the meaning of the coefficients. Of particular interest are the marginal effects of the regressors on various probabilities. The partial derivatives used to capture the marginal effects, as outlined in section III, are evaluated at the mean value of the regressors and are presented in Table 5. For the remainder of this paper, "performing poorly" refers to students who score at Level 0 and Level 1 and "performing well" refers to students who score at Level 3 and Level 4.

[Insert Table 4]

The marginal effects of per pupil administration expenditures indicate that if this regressor increases, then the proportion of students performing poorly increases and the proportion of students performing well decreases. For instance, if per pupil administration expenditures increases by $\$ 100$ for students in the 4'h grade, then the estimated proportion of students performing poorly will increase by $4.7 \%$ and the proportion for those performing well will decrease by 3.6\%. To clarify this point even further, probabilities of performing poorly are evaluated at simulated values of per pupil administration expenditures where other regressors are held at their mean level. For example, if per pupil administration expenditures increases from S100 to $\$ 200$, then the proportion of students performing poorly increases from 34\% to 39\% for the 4 th grade, from $38 \%$ to $41 \%$ for the 8 ' grade, and from $40 \%$ to $42 \%$ for the 12 th grade. More money for administrative purposes most likely occurs at the expense of instruction and hence influences student performance adversely.

\footnotetext{
${ }^{7}$ One could also make a case for reverse causation; i.e., that is, school committees hire more administrators to help school districts with low student performance.
} 
Family background is clearly very important in explaining differences in achievement. Regardless of grade level, students in communities with better educated parents perform better on average. For all three grade levels, the t-ratios associated with the percentage of professionals and managers within a community are positive and significant at the $1 \%$ level. For instance, regarding 4th grade students, if the percentage of professionals and managers within a community increases by one percentage point, then the model predicts a $0.6 \%$ decrease in the proportion of students who perform poorly and a $0.5 \%$ increase in the proportion of students who perform well. Moreover, if the percentage of professionals and managers increases from $30 \%$ to $40 \%$, then the proportion of students performing poorly decreases from $38 \%$ to $32 \%$ in the $4 ' \mathrm{~h}$ grade, from $41 \%$ to $34 \%$ in the 8 th grade, and from $42 \%$ to $37 \%$ in the 12 ' grade. In level terms, of the 238 4th grade students in Abington, this increase in the percentage of professionals and managers leads to an expected decrease in the number of students performing poorly of approximately 14 students and an expected increase in the number of students performing well of approximately 10 students.

[Table 5]

Student achievement is also better in households where both parents are present. The t-ratios for the percentage of single mothers are negative for all grades and are significant at the $1 \%$ level for the 4 ' grade and at the $10 \%$ level for the 8 " grade. These results are consistent with those of Ferguson (1991), who finds that female-headed households and parental education have a statistically significant influence on students' test scores. The two regressors reflecting stability within a community, the percentage of rental units and the crime rate, are all negative and significant at the $1 \%$ level. The only exception occurs in the 12 " grade, where the percentage of rental units is still negatively related to student performance, but insignificant. Probabilities of 
performing poorly are also evaluated at simulated values of the crime rate. If the crime rate increases from $4 \%$ to $8 \%$, then the proportion of students performing poorly increases from $37 \%$ to $44 \%$ in the 4 ' grade, from $40 \%$ to $45 \%$ in the $8 \mathrm{t}^{\mathrm{h}}$ grade, and from $42 \%$ to $47 \%$ in the $12^{\prime}$ grade. Finally, the urban dummy variable is negative and significant only for the 12th grade. Interestingly, whether or not a school district lies in an urban area seems to affect student performance only in the later years. It appears that older students are influenced by all the distractions—-both good and bad—-that urban life offers.

\section{CONCLUSION}

This paper addresses a timely and relevant issue, namely, education reform. Performance, or student quality, appears to be down while resources devoted to schools are dramatically increasing. The statistical contribution of this paper is that it uses a comprehensive data set and offers an econometric approach that captures the peculiar features of MEAP scores. By using an appropriate nonlinear model, not only is the effect of a regressor nonconstant on the probability of a given grade, but also its influence varies across different grades. The explanatory power of the ordered logit model is extremely good as indicated by the LR test and by a comparison of the estimated probabilities to the actual average values. This paper rejects the position that spending more will lead to greater learning. There is no systematic relationship between student performance and per pupil expenditures. Smaller class sizes lead to better student performance, but this finding is restricted to the early years of education. Finally, schools that spend more on administrative expenses consistently report poorer test scores.

The results suggest that socioeconomic factors play a large role in determining student performance. The percentage of professionals and managers, the percentage of single mothers, the percentage of renter occupied units, and the crime rate within a community consistently 
generate significant results. This does not necessarily mean that the poorer, crime-ridden, and less professionally oriented communities do not care about improving their children's education. Nor does it mean that single mothers have any less desire to educate their children. Perhaps it suggests that, because members of the better-off communities can afford to choose alternative means of education, the public schools serving those communities must do a better job in order to continue attracting students.

In short, the condition of public education is, in many respects, distressing. But to argue that this state of affairs can be corrected by increasing expenditures is, at best, misguided. Since other socioeconomic factors do play a key role in explaining student performance, it is to those factors that policymakers should turn their attention.

\section{REFERENCES}

Akerhielm, Karen, "Does Class Size Matter?" Economics of Education Review, 14:3, 1995, 229241.

Amemiya, T., "Qualitative Response Models: A Survey," Journal of Economic Literature, /9:4, 1981, 1,4831,536,

Boardman, A., D. Davis, P. Sanday, "A Simultaneous Equations Model of the Educational Process," Journal of Public Economics, 7:1, 1977, 23-49.

Betts, Julian, "Does School Quality Matter? Evidence from the National Longitudinal Survey of Youth," Review of Economics and Statistics, 77:2, 1995, 231-250.

Card, D., and A. Krueger, "Does School Quality Matter?" Journal of Political Economy, 100:1, 1992, 1-40. 
Coleman, J. S., E. Q. Campbell, C. J. Hobson, J. McPartland, A. M. Mood, F. Weinfeld, and R.

L. York, Equality of Educational Opportunity, U.S. Government Printing Office, Washington, D.C., 1966.

Ferguson, Ronald, "Paying for Public Education: New Evidence on How and Why Money Matters," Harvard Journal on Legislation, 28:2, 1991, 465-498.

Ferguson, Ronald, and Helen Ladd, "How and Why Money Matters: An Analysis of Alabama Schools," in Holding Schools Accountable, Helen Ladd, ed., Brookings institution, Washington, D.C., 1996, 265-298.

Greene, W. H., Econometric Analysis, MacMillan, New York. 1993.

Hanushek, E. A., "The Economics of Schooling: Production and Efficiency in Public Schools," Journal of Economic Literature, 24:3, 1986, 1,141-1,177.

, "The Impact of Differential Expenditures on School Performance," Educational Researcher, /8:4, 1989, 45-51, 62.

, "School Resources and Student Performance," in Does Money Matter? The Link between Schools, Student Achievement, and Adult Success, Gary Bertless, ed., Brookings Institution, Washington, D.C., 1996, 43-73.

Hanushek, E. A., and L. Taylor, "Alternative Assessments of the Performance of Schools," Journal of Human Resources, 25:2. 1990, 179-201.

Hanushek, E. A., S. G. Rivkin, and L. Taylor, "Aggregation and the Estimated Effects of School Resources," Review of Economics and Statistics, 78:4, 1996, 611627.

Heckman, James, Anne Layne-Farrar, and Petra Todd, "Does Measured School Quality Really Matter? An Examination of the Earnings-Quality Relationship," in Does Money Matter? The 
Link between Schools, Student Achievement, and Adult Success, Gary Bert-less, ed., Brookings Institution, Washington, D.C., 1996, 192-289.

Hedges, Larry, and Rob Greenwald, "Have Times Changed? The Relation Between School

Resources and Student Performance," in Does Money Matter? The link between Schools, Student Achievement, and Adult Success, Gary Bertless, ed., Brookings Institution, Washington, D.C., 1996, 74-92.

Hedges, Larry, Richard D. Leine, and Rob Greenwald, "Does Money Matter? A Meta-Analysis of Studies of the Effects of Differential School Inputs on Student Outcomes," Educational Researcher. 23:3, 1994, 5- 14.

Hoxby, Caroline, "How Teachers' Unions Affect Education Production," Quarterly Journal of Economics, 111:3, 1996, 671-718.

Massachusetts Department of State Police, Criminal Information Section, Massachusetts Crime Statistics, 1993.

Massachusetts Executive Office of Education, Massachusetts School District Profiles, September 1993.

Massachusetts Municipal Profiles 1992-93, E. R. Horner, ed., Information Publications, Palo Alto, Calif., 1992.

Sander, William, "Expenditures and student achievement in Illinois," Journal of Public Economics, 52:3, 1993, 403-416.

Stern, David, "Educational Cost Factors and Student Achievement in Grades 3 and 6: Some New Evidence," Economics of Education Review, 8:2, 1989, 149-158. 
U.S. Department of Commerce, 1990 Census of Population and Housing—Population and

Housing Characteristics for Congressional Districts of the 103rd Congress-Massachusetts,

Document No. CPH-4-23, U.S. Government Printing Office, Washington, D.C., 1992.

U.S. Department of Justice, Crime in the United States, U.S. Government Printing Office, Washington, D.C., 1992, 1993.

TABLE 1

Means for Dependent and Independent Variables

\begin{tabular}{|c|c|c|c|}
\hline & $\begin{array}{c}\text { Grade 4 } \\
\text { Mean }(n=148)\end{array}$ & $\begin{array}{c}\text { Grade } 8 \\
\text { Mean }(n=151)\end{array}$ & $\begin{array}{c}\text { Grade 12 } \\
\text { Mean }(n=144)\end{array}$ \\
\hline \multicolumn{4}{|l|}{ Dependent variables: Percentage of Students } \\
\hline Level $<1$ & $\begin{array}{l}4.56 \\
(4.86)_{\mathrm{a}}\end{array}$ & $\begin{array}{c}7.05 \\
(7.12)\end{array}$ & $\begin{array}{c}9.49 \\
(9.80)\end{array}$ \\
\hline Level 1 & $\begin{array}{c}32.09 \\
(31.23)\end{array}$ & $\begin{array}{c}31.88 \\
(32.11)\end{array}$ & $\begin{array}{c}30.72 \\
(31.05)\end{array}$ \\
\hline \multirow[t]{2}{*}{ Level 2} & 40.12 & 30.70 & 27.07 \\
\hline & $(40.89)$ & $(31.25)$ & $(27.02)$ \\
\hline Level 3 & $\begin{array}{c}20.15 \\
(19.99)\end{array}$ & $\begin{array}{c}24.44 \\
(24.12)\end{array}$ & $\begin{array}{l}24.85 \\
(24.47)\end{array}$ \\
\hline Level 4 & $\begin{array}{l}3.08 \\
(3.02)\end{array}$ & $\begin{array}{c}5.94 \\
(5.39)\end{array}$ & $\begin{array}{c}7.87 \\
(7.65)\end{array}$ \\
\hline \multicolumn{4}{|l|}{ Independent Variables } \\
\hline Per pupil expenditures ${ }^{b}$ & 3.85 & 4.70 & 5.27 \\
\hline Teacher-pupil ratio & 6.41 & 6.45 & 6.52 \\
\hline Per pupil administration expenditures ${ }^{c}$ & 1.47 & 1.50 & 1.50 \\
\hline Percentage of professionals/managers & 32.41 & 32.20 & 31.98 \\
\hline Percentage of single mothers & 5.14 & 4.93 & 4.92 \\
\hline Percentage of renter occupied units & 28.54 & 28.25 & 28.01 \\
\hline Crime rate & 3.41 & 3.45 & 3.47 \\
\hline Urban & 22.97 & 23.18 & 22.92 \\
\hline
\end{tabular}

alues in parentheses represent estimated probabilities calculated at the mean regressors. Section IV explores this issue.

bData on per pupil expenditures are expressed in thousands of dollars.

${ }^{c}$ Data on per pupil administration expenditures are expressed in hundreds of dollars. 
TABLE 2

Estimated Ordered Logit Models: Grade $4(n=148)$

\begin{tabular}{|c|c|c|c|}
\hline Variable & Final Model & $\begin{array}{l}\text { Model Excluding } \\
\text { Teacher-Pupil Ratio } \\
\text { and Administration } \\
\text { Expenditures }\end{array}$ & $\begin{array}{c}\text { Model Excluding } \\
\text { Per Pupil } \\
\text { Expenditures }\end{array}$ \\
\hline Constant & $\begin{array}{r}2.891^{*} \\
(13.420)^{\mathrm{a}}\end{array}$ & $\begin{array}{r}3.206^{*} \\
(17.294)\end{array}$ & $\begin{array}{r}2.905^{*} \\
(13.727)\end{array}$ \\
\hline Per pupil expenditures & $\begin{array}{c}-0.049 \\
(-1.174)\end{array}$ & $\begin{array}{l}-0.0743^{*} \\
(-1.907)\end{array}$ & - \\
\hline Teacher-pupil ratio & $\begin{array}{l}0.054^{* *} \\
(1.569)\end{array}$ & - & $\begin{array}{c}0.038 \\
(1.173)\end{array}$ \\
\hline Per pupil administration expenditures & $\begin{array}{l}-0.202^{*} \\
(-3.958)\end{array}$ & - & $\begin{array}{l}-0.216^{*} \\
(-4.452)\end{array}$ \\
\hline Percentage of professionals/managers & $\begin{array}{c}0.026^{*} \\
(6.171)\end{array}$ & $\begin{array}{c}0.020^{*} \\
(4.789)\end{array}$ & $\begin{array}{c}0.024^{*} \\
(6.309)\end{array}$ \\
\hline Percentage of single mothers & $\begin{array}{l}-0.016^{*} \\
(-2.557)\end{array}$ & $\begin{array}{l}-0.015^{*} \\
(-2.565)\end{array}$ & $\begin{array}{l}-0.016^{*} \\
(-2.679)\end{array}$ \\
\hline Percentage of renter occupied units & $\begin{array}{r}-0.009^{*} \\
(-3.128)\end{array}$ & $\begin{array}{l}-0.007^{*} \\
(-2.709)\end{array}$ & $\begin{array}{l}-0.009^{*} \\
(-3.383)\end{array}$ \\
\hline Crime rate & $\begin{array}{r}-0.075^{*} \\
(-3.939)\end{array}$ & $\begin{array}{l}-0.079^{*} \\
(-3.766)\end{array}$ & $\begin{array}{l}-0.077^{*} \\
(-4.167)\end{array}$ \\
\hline Urban & $\begin{array}{c}-0.001 \\
(-1.083)\end{array}$ & $\begin{array}{l}-0.001^{* *} \\
(-1.470)\end{array}$ & $\begin{array}{c}-0.001 \\
(-1.027)\end{array}$ \\
\hline LR test statistic: $\chi^{2}(\mathrm{df}=8)$ & $3384.17^{*}$ & & \\
\hline
\end{tabular}

${ }^{\mathrm{a}}$ Values in parentheses are t-ratios. The LR test verifies the overall significance of the eight regressors in the final model.

* and ** indicate significance at 0.01 and 0.10 levels, respectively. 
TABLE 3

Estimated Ordered Logit Models: Grade $8(n=151)$

\begin{tabular}{|c|c|c|c|}
\hline Variable & Final Model & $\begin{array}{c}\text { Model Excluding } \\
\text { Teacher-Pupil Ratio } \\
\text { and Administration } \\
\text { Expenditures }\end{array}$ & $\begin{array}{c}\text { Model Excluding } \\
\text { Per Pupil } \\
\text { Expenditures }\end{array}$ \\
\hline Constant & $\begin{array}{r}2.360^{*} \\
(12.082)^{\mathrm{a}}\end{array}$ & $\begin{array}{r}2.433^{*} \\
(19.068)\end{array}$ & $\begin{array}{r}2.356^{*} \\
(12.680)\end{array}$ \\
\hline Per pupil expenditures & $\begin{array}{c}-0.005 \\
(-0.156)\end{array}$ & $\begin{array}{c}-0.021 \\
(-1.004)\end{array}$ & - \\
\hline Teacher-pupil ratio & $\begin{array}{c}0.005 \\
(0.153)\end{array}$ & - & $\begin{array}{c}0.003 \\
(0.119)\end{array}$ \\
\hline Per pupil administration expenditures & $\begin{array}{l}-0.106^{*} \\
(-2.373)\end{array}$ & - & $\begin{array}{c}-0.108^{*} \\
(-2.511)\end{array}$ \\
\hline Percentage of professionals/managers & $\begin{array}{c}0.029^{*} \\
(9.566)\end{array}$ & $\begin{array}{c}0.025^{*} \\
(8.627)\end{array}$ & $\begin{array}{r}0.029^{*} \\
(10.648)\end{array}$ \\
\hline Percentage of single mothers & $\begin{array}{l}-0.018 * * \\
(-1.278)\end{array}$ & $\begin{array}{c}-0.012 \\
(-0.891)\end{array}$ & $\begin{array}{l}-0.018^{* *} \\
(-1.301)\end{array}$ \\
\hline Percentage of renter occupied units & $\begin{array}{l}-0.0111^{*} \\
(-5.342)\end{array}$ & $\begin{array}{c}-0.011^{*} \\
(-4.884)\end{array}$ & $\begin{array}{c}-0.011^{*} \\
(-5.476)\end{array}$ \\
\hline Crime rate & $\begin{array}{c}-0.049^{*} \\
(-2.985)\end{array}$ & $\begin{array}{l}-0.055^{*} \\
(-2.938)\end{array}$ & $\begin{array}{c}-0.048^{*} \\
(-2.988)\end{array}$ \\
\hline Urban & $\begin{array}{c}0.000 \\
(0.076)\end{array}$ & $\begin{array}{l}-0.000 \\
(-0.121)\end{array}$ & $\begin{array}{c}0.000 \\
(0.087)\end{array}$ \\
\hline LR test statistic: $\chi^{2}(\mathrm{df}=8)$ & $2922.76^{*}$ & & \\
\hline
\end{tabular}

${ }^{a}$ Values in parentheses are t-ratios. The LR test verifies the overall significance of the eight regressors in the final model.

* and ** indicate significance at 0.01 and 0.10 levels, respectively. 
TABLE 4

Estimated Ordered Logit Models: Grade $12(n=144)$

\begin{tabular}{|c|c|c|c|}
\hline Variable & Final Model & $\begin{array}{l}\text { Model Excluding } \\
\text { Teacher-Pupil Ratio } \\
\text { and Administration } \\
\text { Expenditures }\end{array}$ & $\begin{array}{c}\text { Model Excluding } \\
\text { Per Pupil } \\
\text { Expenditures }\end{array}$ \\
\hline Constant & $\begin{array}{c}2.275^{\star} \\
(10.313)^{\mathrm{a}}\end{array}$ & $\begin{array}{c}2.070^{*} \\
(9.393)\end{array}$ & $\begin{array}{r}2.388^{*} \\
(11.708)\end{array}$ \\
\hline Per pupil expenditures & $\begin{array}{c}0.047 \\
(1.126)\end{array}$ & $\begin{array}{c}0.000 \\
(0.004)\end{array}$ & - \\
\hline Teacher-pupil ratio & $\begin{array}{c}-0.065^{*} \\
(-1.989)\end{array}$ & - & $\begin{array}{l}-0.054^{* *} \\
(-1.647)\end{array}$ \\
\hline Per pupil administration expenditures & $\begin{array}{c}-0.075 \\
(-1.251)\end{array}$ & - & $\begin{array}{c}-0.056 \\
(-0.950)\end{array}$ \\
\hline Percentage of professionals/managers & $\begin{array}{r}0.019^{*} \\
(5.210)\end{array}$ & $\begin{array}{c}0.016^{*} \\
(4.043)\end{array}$ & $\begin{array}{c}0.020^{*} \\
(5.891)\end{array}$ \\
\hline Percentage of single mothers & $\begin{array}{c}-0.019 \\
(-0.925)\end{array}$ & $\begin{array}{c}-0.011 \\
(-0.529)\end{array}$ & $\begin{array}{c}-0.025 \\
(-1.226)\end{array}$ \\
\hline Percentage of renter occupied units & $\begin{array}{c}-0.001 \\
(-0.484)\end{array}$ & $\begin{array}{c}-0.001 \\
(-0.145)\end{array}$ & $\begin{array}{c}-0.001 \\
(-0.214)\end{array}$ \\
\hline Crime rate & $\begin{array}{r}-0.058^{*} \\
(-3.006)\end{array}$ & $\begin{array}{r}-0.068^{*} \\
(-3.223)\end{array}$ & $\begin{array}{r}-0.057^{*} \\
(-2.890)\end{array}$ \\
\hline Urban & $\begin{array}{c}-0.002^{*} \\
(-2.402)\end{array}$ & $\begin{array}{l}-0.002^{*} \\
(-2.547)\end{array}$ & $\begin{array}{c}-0.002 \\
(-2.358)\end{array}$ \\
\hline LR test statistic: $\chi^{2}(\mathrm{df}=8)$ & $1645.63^{*}$ & & \\
\hline
\end{tabular}

"Values in parentheses are t-ratios. The LR test verifies the overall significance of the eight regressors in the final model.

* and ** indicate significance at 0.01 and 0.10 levels, respectively.

TABLE 5

Estimated Partial Derivatives Evaluated at Mean Regressors

\begin{tabular}{|c|c|c|c|c|c|c|}
\hline \multirow[b]{2}{*}{ Variable } & \multicolumn{3}{|c|}{$P$ (Performing Poorly) } & \multicolumn{3}{|c|}{ P (Performing Well) } \\
\hline & Grade 4 & Grade 8 & Grade 12 & Grade 4 & Grade 8 & Grade 12 \\
\hline Per pupil expenditures & * & - & $\bullet$ & * & $\bullet$ & * \\
\hline Teacher-pupil ratio & -0.012 & * & 0.016 & 0.100 & • & -0.014 \\
\hline Per pupil administration expenditures & 0.047 & 0.025 & * & -0.036 & -0.022 & • \\
\hline Percentage of professionals/managers & -0.006 & -0.007 & -0.005 & 0.005 & 0.006 & 0.004 \\
\hline Percentage of single mothers & 0.004 & 0.004 & * & -0.003 & -0.004 & * \\
\hline Percentage of renter occupied units & 0.002 & 0.003 & * & -0.002 & -0.002 & $*$ \\
\hline Crime rate & 0.017 & 0.012 & 0.014 & -0.013 & -0.010 & -0.013 \\
\hline Urban & $\bullet$ & * & 0.000 & * & * & -0.000 \\
\hline
\end{tabular}

Notes: $P$ (Performing Poorly $)=P(y=0)+P(y=1)$ and $P($ Performing Well $)=P(y=3)+P(y=4)$. These probabilities capture the partial effect of various regressors on student performance.

- indicates regressor is insignificant for this grade level. This table excludes regressors that are insignificant for all three grade levels. 